\title{
Identification of platyhelminth parasites of the wild bullseye pufferfish (Sphoeroides annulatus Jenyns, 1853) using invariant digital color correlation
}

\author{
Identificación de parásitos platelmintos del botete silvestre (Sphoeroides annulatus \\ Jenyns, 1853) usando una correlación invariante digital a color \\ Josué Álvarez-Borrego ${ }^{1}$ and Emma Josefina Fájer-Ávila² \\ ${ }^{1}$ Centro de Investigación Científica y de Educación Superior de Ensenada, Dirección de Física Aplicada, Departamento de Óptica, \\ km 107, Carretera Tijuana-Ensenada, Ensenada, B. C., México, C.P. 22860 \\ ${ }^{2}$ Centro de Investigación en Alimentación y Desarrollo, A.C., Unidad Mazatlán en Acuicultura y Manejo Ambiental. Av. Sábalo \\ Cerritos s/n, Estero del Yugo, C.P. 82010, A.P. 711, Mazatlán, Sinaloa, México \\ josue@cicese.mx
}

Resumen.- La identificación específica de parásitos utilizando técnicas morfológicas son lentas y consumidoras de tiempo, requiriendo preparaciones de alta calidad donde cada estructura taxonómicamente importante pueda ser observada con claridad, y además debe llevarse a cabo una consulta con un experto en taxonomía. La información de color llega a ser un importante rasgo discriminativo, el cual necesitamos incluir en el proceso completo de identificación. Imágenes digitales de las monogeneas Heterobothrium ecuadori y Neobenedenia melleni, y las digeneas Lintonium vibex, Homalometron longisinosum, Bianium plicitum y Phyllodistomum mirandai, fueron procesadas para obtener la magnitud de su transformada de Fourier para proveer un método rápido para identificar parásitos por profesionales no expertos en sistemática. Se llevó a cabo una simulación numérica para correlacionar la magnitud de la transformada de Fourier de las diferentes especies de parásitos con filtros sólo de fase. El reconocimiento de la imagen invariante a posición, rotación y a escala fue llevada a cabo a través del uso de la transformada de escala y un mapeo polar. Hemos desarrollado un método exitoso para la descriminación entre especies parásitas de platelmintos. Para maximizar el potencial de este método, es necesario tener un gran banco de datos de este tipo de imágenes, el cual debería incluir imágenes digitales de las principales especies de parásitos encontrados para que de esta forma apliquemos esta técnica y continuar así con esta investigación. Este trabajo es una base para el desarrollo de un sistema automatizado para la identificación de parásitos en Sphoeroides annulatus.

Palabras clave: Técnicas de identificación, sistemas automatizados, helmintos
Marine fish culture in Mexico was less than 7.5 tons in 1999 (FAO 2000), but has good potential for growth considering that Mexico has an extensive coastline and a strong shrimp aquaculture industry. The bullseye puffer fish, Sphoeroides annulatus Jenyns, 1853, is an important species in local fisheries in the East coast of the Mexican Pacific. Recent studies show that this puffer fish is a species with potential to aquaculture development (Duncan et al. 2003).

Helminths are among the most common parasites of marine fish but their biodiversity is heavily underestimated because of the huge number of helminth species and consequently difficulties in their identification (Pérez-Ponce et al. 1999). The need to identify helminth parasites is increasing since the development of aquaculture in the last few decades has been seriously affected by parasite problems that decrease production (Kennedy 1994).

Systematic parasitology has made significant contributions in tropical medicine, public health and studies of biodiversity and evolutionary biology. Systematists are key to parasitology and associated disciplines but despite this, fewer expert morphologists are being trained and the number of active systematists decreases yearly (Brooks 2000). The specific identification of parasites using morphological data can 
be slow and time consuming, requiring quality preparations so that each taxonomically important structure can be clearly observed. Analysis of these structures, comparison with keys, consultation of relevant literature, and recording of morphometric data are all required for parasite identification using established techniques.

The application of new techniques in biosystematics is a real possibility. Accurate molecular techniques have been developed for instance, to identify some species of helminth parasites (Mattiuci et al. 2000). Others studies show that image processing is a technique that can give reliable results. Gubanyi (1995) and Shinn et al. (1996) refer to the use of image processing and morphometric programs for the identification of species of helminth parasites. Székely (1997) has also discussed the possible applications of video and digital images of fish parasites to examine the morphology of the protozoan groups Apicomplexa and Myxosporea. Work in this area is concentrating on developing techniques that will allow systematists to identify parasite species.

Zavala-Hamz et al. (1996) and Zavala-Hamz \& Álvarez-Borrego (1997) completed a study using diffraction patterns and circular harmonic filters as a tool to identify copepods and showed that these techniques could discriminate between two species, the sexes of each species, and could identify the species from fragments of the organism. Furthermore PechPacheco \& Álvarez-Borrego (1998) with an opticaldigital system, were able to identify five important phytoplankton species as bioindicators of red tides. The precision of the technique was $90 \%$ regardless of the size, position, or orientation of the sample. PechPacheco et al. (1999) presented the use of diffraction patterns in the identification of six Ceratium species and overcame the numerous problems like image background (detritus, lighting variation in the microscope), variation in cell sedimentation in the observation field, natural morphological variation of the species in a sample, intra- and interspecific problems, and organism fragmentation. Álvarez-Borrego \& Chávez-Sánchez (2001) demonstrated that color digital correlation can be used to detect the virus IHHN in shrimp tissues. Recognition of Vibrio cholerae 01 using color correlation in a coherent optical system (MouriñoPérez 1999) and using a invariant digital correlation (Alvarez-Borrego et al. 2002) has also been achieved.

Recent studies undertaken by Fajer et al. (2004) on the helminth parasites of the wild "botete diana" puffer fish from the state of Sinaloa, Mexico revealed the presence of two monogenean species, and four digeneans. These studies provided whole mount specimens necessary to examine a new method of parasites identification. The proposed aims were to discriminate among six helminth species found in the wild bullseye by invariant digital color correlation. Our results suggest that this technique can provide a rapid method for the identification of parasites by systematists.

\section{Materials and methods}

The parasites used in this study were collected from 226 wild Sphoeroides annulatus Jenyns, 1853 (bullseye puffer fish) caught from two locations in the State of Sinaloa, Mexico (Teacapan $22^{\circ} 32^{\prime} \mathrm{N}-105^{\circ} 44^{\prime} \mathrm{W}$ and Mazatlan $23^{\circ} 11^{\prime} \mathrm{N}-106^{\circ} 25^{\prime} \mathrm{W}$ ) during three spawning seasons (1999, 2000, and 2001). Each fish was examined for helminth ectoparasites on gills and fins, and from body surface scrapes, as well as for endoparasites from the internal organs, e.g. air sacs, intestines, and urinary bladders. All helminths recovered were flattened between a cover slip and a glass slide, fixed with 70\% alcohol, stained with Semichon's acetocarmine and mounted in Canada balsam. For this study, we selected a number of parasites identified by morphological methods. Parasites included the monogeneans Heterobothrium ecuadori (He) and Neobenedenia melleni (Nm), ectoparasites from the gills and skin, respectively, and the digeneans Lintonium vibex (Lv) and Phyllodistomum mirandai (Pm), endoparasites from the air sacs and urinary bladder, respectively, and Bianium plicitum (Bm) and Homalometron longisinosum $(\mathrm{Hl})$ from the intestines. Paratypes were deposited in CIAD, A. C., Unidad Mazatlan, Sinaloa, Mexico (He cat. No MO1-373-38; Nm cat. $\mathrm{N}^{\mathrm{o}} \mathrm{M} 00-410-39$; Lv cat. $\mathrm{N}^{\mathrm{o}}$. T00-10-04; Pm cat. $\mathrm{N}^{\circ}$. T98-00-1; Bm cat. No. T00-102-12; Hl cat. No. T0099-02, and in Instituto de Biología, Universidad Nacional Autónoma de México (UNAM) in Mexico City (He cat. No 4287; Nm cat. $N^{o} 4286$; Lv, cat. $\mathrm{N}^{\circ}$. 4284; Pm cat. No. 4285; Bm cat. No. 4288; Hl cat. $N^{\circ}$. 4289).

Our method of invariant correlation uses speciesspecific composite filters which includes information of morphological variations of each target species. The composite filter was built by several images of the same species. To discriminate Homalometron longisinosum $(\mathrm{Hl}), 4$ images were chosen to build the composite filter; 
to discriminate Bianium plicitum (Bp) 10 images; for Heterobothrium ecuadori (He) 10 images; for Lintonium vibex (Lv) 10 images; for Neobenedenia melleni (Nm) 10 images and for Phyllodistomum mirandai (Pm) 4 images were chosen. The number of images depends of the morphological complexity. In order to test the species-specific composite filters, we used 193 images, 9 images for $\mathrm{Hl}, 31$ images for Bp, 48 images for He, 46 images for Lv, 46 images for $\mathrm{Nm}$ and 13 images for Pm.

By means of a high resolution video camera (Sony CCD IRIS) connected to a stereomicroscope (Leica
Microsystems Wetzlar, Germany), and the program Pixel View installed on a Dell Dimension 4100 computer, color images of the parasites were recorded under objective lens of $0.63,1,1.6,2.5$ or $4 \mathrm{X}$ according parasite size. The size of the images $(f(x, y))$ was 256 x 256 pixels.

A numerical simulation was performed to correlate Fourier transform magnitude of parasites species with phase-only filters (for more details see Horner \& Gianino 1984).

\section{Figure 1}

Method for obtaining the species-specific composite filters. $f_{1}, f_{\triangleright}, \ldots, f_{n}$ are the morphologies of the parasites images; FFT is the Fourier transform of each image; $F_{1}\left(w_{x}, w_{y}\right),\left|F_{2}\left(w_{x}, w_{y}\right), \ldots,\right| F_{n}\left(w_{x}, w_{y}\right)$ are the modulus of the Fourier transform and $w_{x}, w_{y}$ are the coordinates in the Fourier plane (frequencies content of the image); $\mid F\left(w_{x}, w_{y}\right)$ is the sum of all modulus; $F(r, \theta)$ is the polar plane and $S_{P O F}\left(u_{\rho}, v_{\theta}\right)$ is the species-specific composite phase only filter where $u_{\rho}$ and $v_{\theta}$ are the new coordinates.

Método para obtener los filtros compuestos de la especie-específica. $f_{1}, f_{2}, \ldots, f_{n}$ son las morfologías de las imágenes de los parásitos; FFT es la transformada de Fourier de cada imagen; $\left|F_{1}\left(w_{x}, w_{y}\right),\right| F_{2}\left(w_{x}, w_{y}\right), \ldots, \mid F_{n}\left(w_{x}, w_{y}\right)$ son los módulos de la transformada de Fourier y $w_{x}, w_{y}$ son las coordenadas en el plano de Fourier (contenido de frecuencias de la imagen); $\mid F\left(w_{x}, w_{y}\right)$ es la suma de todos los módulos; $F(r, \theta)$ es el plano polar y $S_{P O F}\left(u_{\rho}, v_{\theta}\right)$ es el filtro compuesto sólo de fase de la especie-específica donde $u_{\rho}$ y $v_{\theta}$ son las nuevas coordenadas

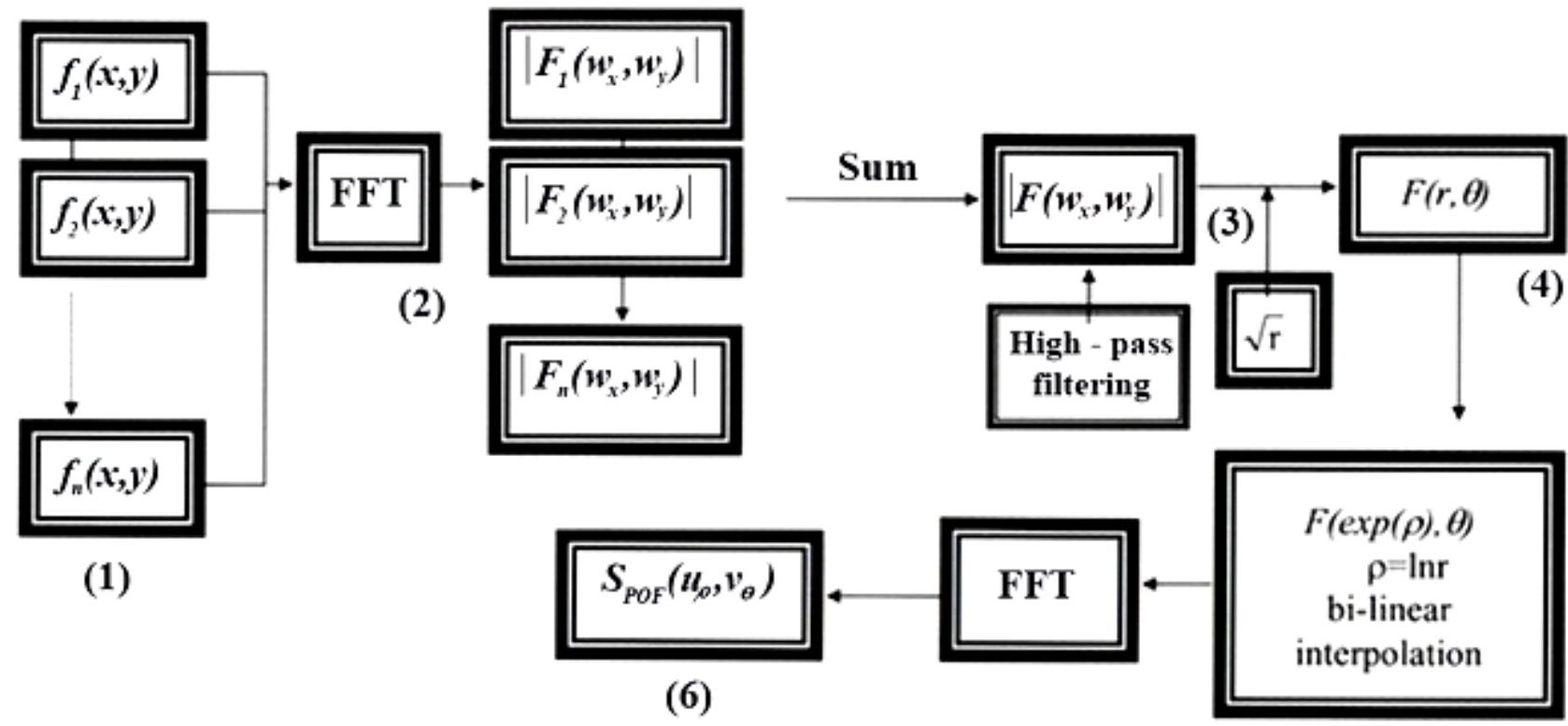


The method for obtaining the composite filters is presented in Fig. 1. Since parasites have variable morphologies (e.g. according to size, quality preparation and staining) it is necessary to include this information in the filters. The first step (Step 1) is to choose all the different morphologies for a single species, $f_{1}(x, y), f_{2}(x, y), \ldots, f_{n}(x, y)$, and to obtain the modulus of the Fourier transform (frequency content) of each one, $\left|F_{1}\left(w_{x}, w_{y}\right)\right|,\left|F_{2}\left(w_{x}, w_{y}\right)\right|, \ldots,\left|F_{n}\left(w_{x}, w_{y}\right)\right|$ (Step 2), is to sum all the moduli to produce a single image (Step 3). This provides, in a single matrix, all the frequency information related to the morphology of the species to be recognized. In Step 3, it is not necessary to use a uniform scale and orientation for the images since the final product is scale and orientation invariant. The high frequencies are then enhanced using high-pass filtering (parabolic function). This weighting towards high frequencies will help improve the identification of the "unknown" species to be recognized. A scale factor $\sqrt{r}$ is then applied. This process is what differentiates the scale transform from the Mellin-transform. After these steps, the Cartesian coordinates were mapped to polar coordinates to obtain invariance to rotation (Step 4). In Step 5, a bilinear interpolation of the first coordinate conversion data is introduced (for more details see Pech-Pacheco et al. 2003). This is done to minimize sampling error which affects the identification of the "unknown" species. The resulting image (Step 6) is the species-specific composite filter which will be used in the invariant correlation with data arising from images of individual helminth specimens. $\mathrm{S}_{\mathrm{POF}}$ is the name used for the species-specific composite phase only filter obtained in Step 6. Steps 3, 4, 5, and 6 from Fig. 1 are necessary to ensure that the information contained in the Fourier transform magnitude is invariant to rotation, scale, and position, thus obtaining correlation invariant of the Fourier transform magnitude. Because color images, one species-specific composite filter was made for each RGB channel. The explanation for Fig. 2 is exactly the same like Fig. 1. A fuller discussion of this technique (considering a single filter only) is given in Alvarez-Borrego et al. (2002).

Figure 2

Invariant correlation to position, rotation and scale. $f(x, y)$ is the unknown species to be recognized; $\mid F\left(w_{x}, w_{y}\right)$ is the modulus of the Fourier transform (modulus of the frequencies content) of the unknown image; $F(r, \theta)$ is the polar plane like Fig. 1 and $S\left(u_{\rho}, v_{\theta}\right)$ is the phase information of the unknown species with the position, rotation and scale information Correlación invariante a posición, rotación y escala. $f(x, y)$ es la especie desconocida que va a ser reconocida; $\left|F\left(w_{x}, w_{y}\right)\right|$ es el módulo de la transformada de Fourier (módulo del contenido de frecuencias) de la imagen desconocida; $F(r, \theta)$ es el plano polar como en la Fig. 1 y $S\left(u_{\rho}, v_{\theta}\right)$ es la información de fase de la especie desconocida con la información de la posición, rotación y escala

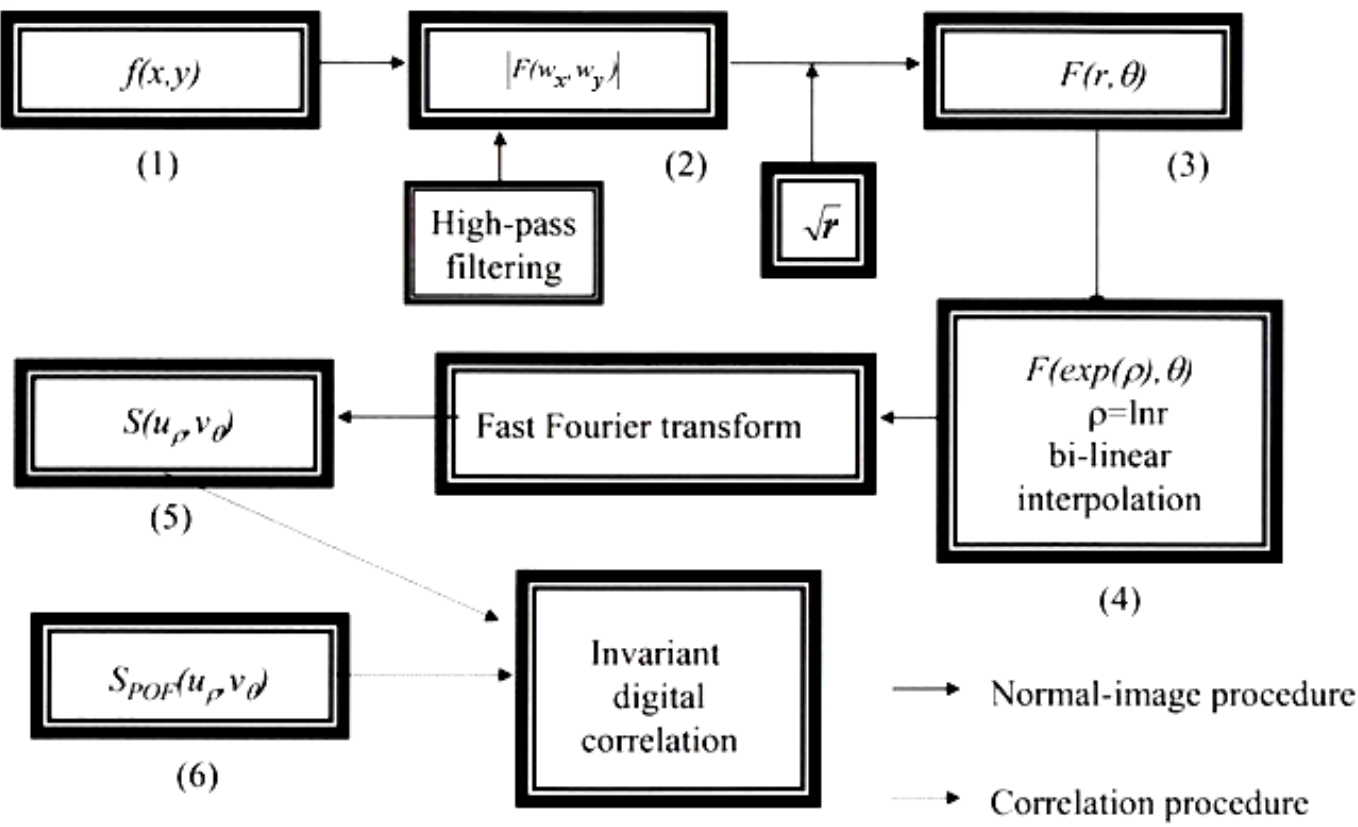

(7) 
To discriminate among parasite species, images of each individual to be recognized were transformed as indicated in Fig. 2, which mirrors Fig. 1, except that in Step 1 only a single image provides the input. In Step 5, $\mathrm{S}$ is the name used for the "unknown" species to be recognized. In Step 6, we can see the results obtained using the same steps as Fig. 1. In Step 7 of Fig. 2, the invariant digital correlation is made between the parasite to be recognized and the individual speciesspecific composite filters.

The recognition of particular species of parasite is complex. Color can be an important discriminative feature, which needs to be included for successful identification.

Since our analysis was digital, it was possible to separate the color image in 3 channels (RGB) using pixel view. Thus, the process shown in Fig. 2 was repeated for each channel (R, G, and B). In each color channel, the composite filter to be used is matched to the corresponding component of the target. In general, objects which have a determined component $A_{\lambda i}(x, y)$ similar to the respective component of the target $P_{\lambda_{i}}(x, y)$ will give a maximum correlation in this channel $\left(\lambda_{i}\right)$. Only the target will give a correlation maximum in all channel. So, an object is detected as the target if it simultaneously produces a correlation peak in the 3 channels. The final result will be the product of the correlation for each of the RGB channels multiplied. The digital correlations were performed by an algorithm specifically built by us using MATLAB software (Copyright 1984-2000, The Mathworks, Inc.). The algorithm allows the different steps showed in Figs. 1 and 2.

\section{Results and discussion}

The parasites studied are shown in Fig. 3. In order to illustrate the method used in this study, six parasite species were analysed.

The mean correlation values obtained for each species-specific composite filter against all the images to identify are presented as box plots and for each the mean, standard error (SE) and two times the standard error $(2 * \mathrm{SE})$ are represented (Figs. 4, 5 and 6). Correlation values are normalized. Figures represent the mean correlation for multiple individuals of each species.
The results for $\mathrm{Hl}$ and for $\mathrm{Bp}$ are shown in Fig. 4. For both species the figure shows the product of multiplying RGB channels. In each figure, the $\mathrm{X}$-axis shows the filter for each species-specific composite and the $\mathrm{Y}$-axis give us the mean invariant correlation value obtained for test individuals of a given species. For Homalometron longisinosum a mean value of $0.75 \pm 0.12$ $( \pm 1 \mathrm{SE})$ was obtained, when the filter $\mathrm{Hl}$ was correlated with all the six parasite species (Fig. 4a). These values were separated from the correlation values obtained for other species to a $95 \%$ of confidence. In Fig. $4 \mathrm{~b}$ the correlation values obtained for Bianium plicitum with the filter $\mathrm{Bp}$ are presented. A mean value of $0.43 \pm 0.08$ (1SE) was obtained. These values are completely separated from the values of the other parasites species.

Figs. 4 and 5 show the results for He and Lv. The correlation values for Heterobothrium ecuadori with the He filter had a mean value of $0.84 \pm 0.04$ ( $\pm 1 \mathrm{SE}$ ) (Fig. $5 a)$. The correlation for Lintonium vibex with the Lv filter had a mean of $0.51 \pm 0.04( \pm 1 \mathrm{SE})$. These values were also separated from the mean value obtained for the other parasite species.

The mean correlation value obtained for Neobenedenia melleni with the Nm filter and the mean value for Phyllodistomum mirandai with the Pm filter were $0.53 \pm 0.09( \pm 1 \mathrm{SE})$ and $0.67 \pm 0.16( \pm 1 \mathrm{SE})$ respectively (Figs. 6a, b), which were also separated from the mean values obtained for other species.

This work is only a first step to develop an automatical system which can be used by non-systematists to identify parasites and also for processing a lot of samples in considerably short time. The time used in to identify or not an image of a parasite with this digital system is less than 8 seconds.

The results obtained from the techniques employed in the present report are very good, considering the complexity of the morphology of parasitic platyhelminths. Different numbers of worm images were used to build and test the species-specific composite filters, because the morphology and the number of samples are different for each species. The best way is to use few images ( $<10$, in practical sense) because with each image added increase noise in the identification process. 


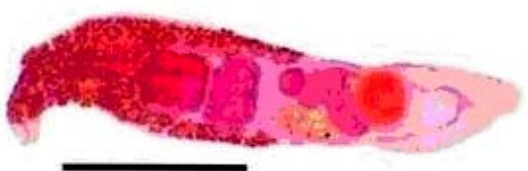

Homalometron longisinosum

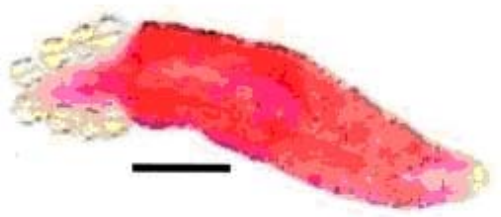

Heterobothrium ecuadori

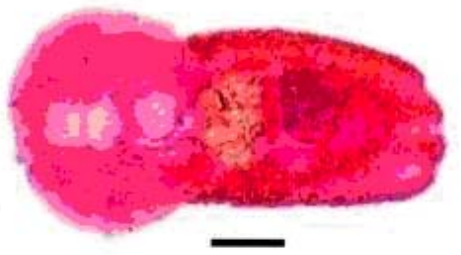

Bianium plicitum

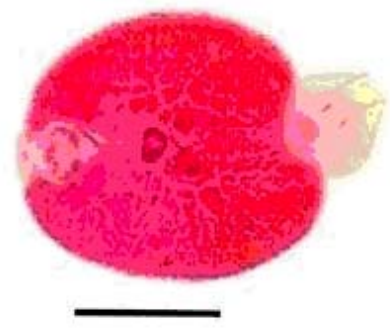

Neobenedenia melleni

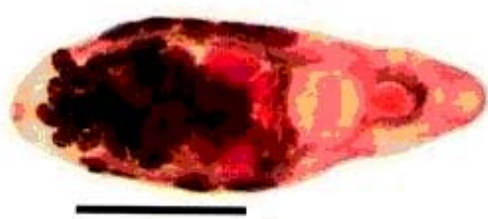

Lintonium vibex

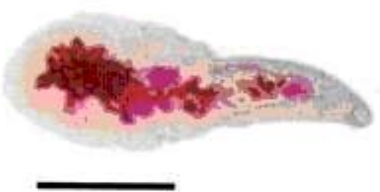

Phyllodistomum mirandai

\section{Figure 3}

Helminth species studied in this paper (planar view, stained with Semichon's acetocarmine). Scale bars: Hl, Nm, He, Lv: 1mm; Bp, Pm: 0.5 mm

Especies de helmintos estudiadas en este artículo (vista planar, teñidos con acetocarmina de Semichon). Escala de la barras: Hl, Nm, He, Lv: 1mm; Bp, Pm: 0,5 mm 

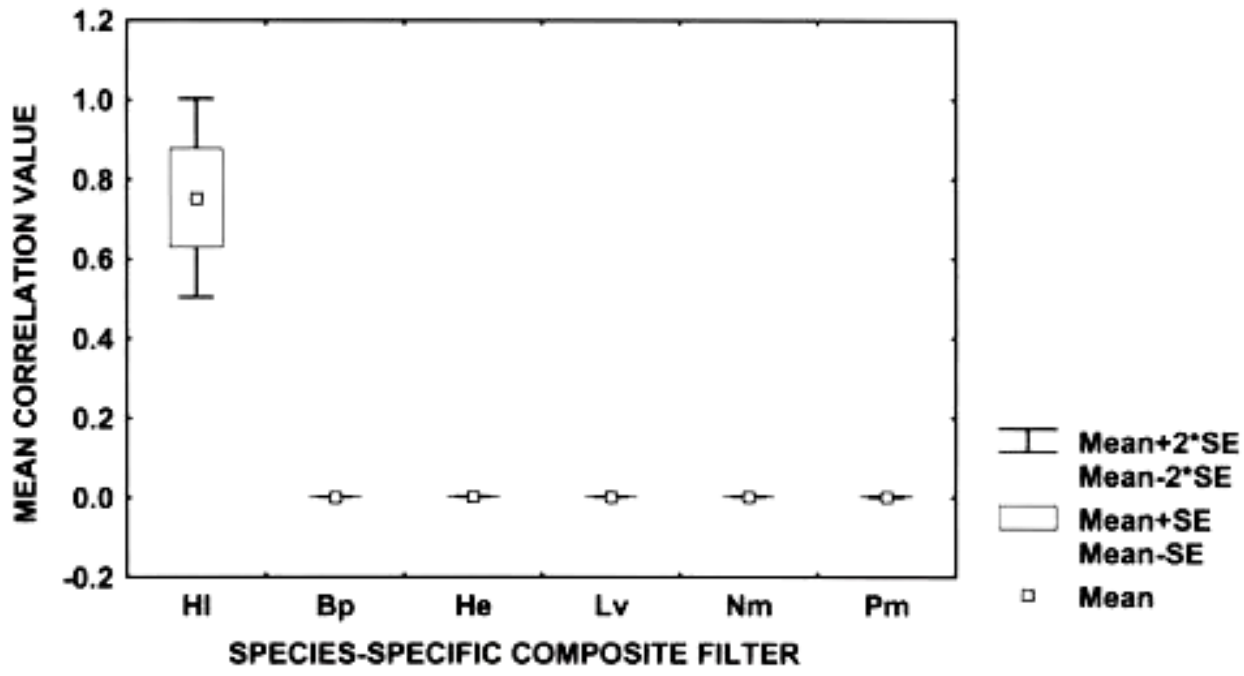

(a)
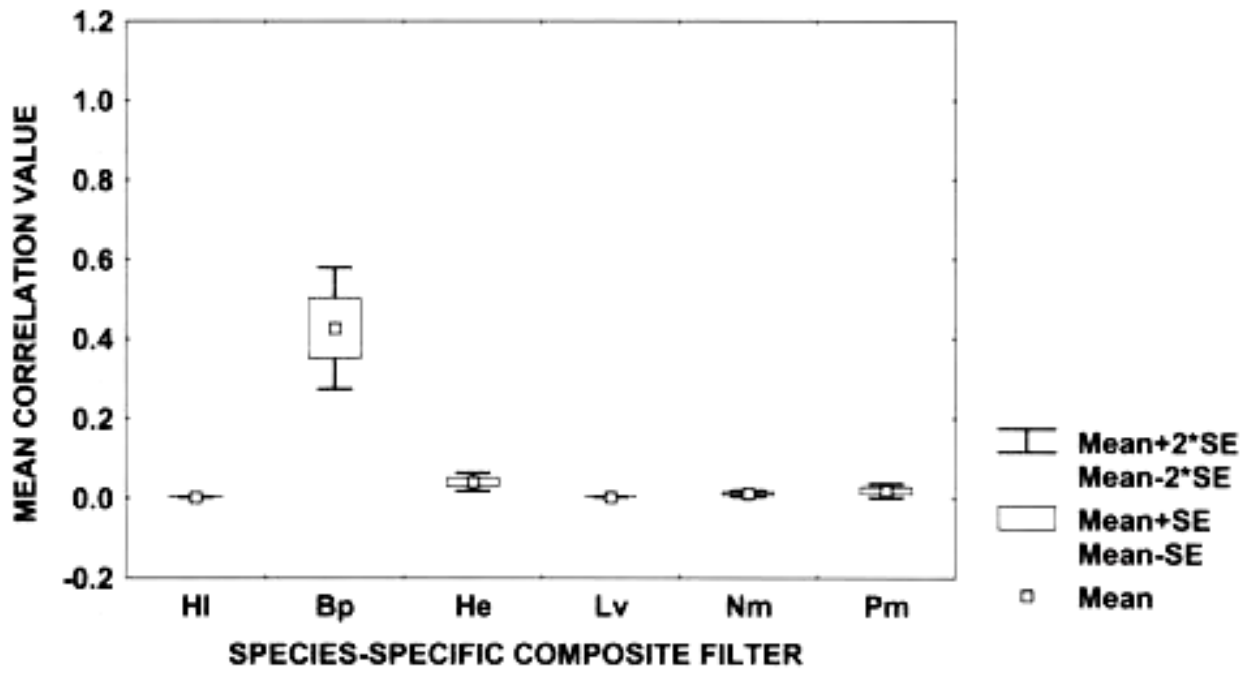

(b)

Figure 4

Correlation results for a) Homalometron longisinosum (Hl) and b) Bianium plicitum (Bp). Boxplots show mean correlation for product of 3 color channels (RGB)

Resultados de la correlación para a) Homalometron longisinosum (Hl) and b) Bianium plicitum (Bp).

Los dibujos de caja muestran la correlación promedio como producto de los 3 canales de color (RGB) 

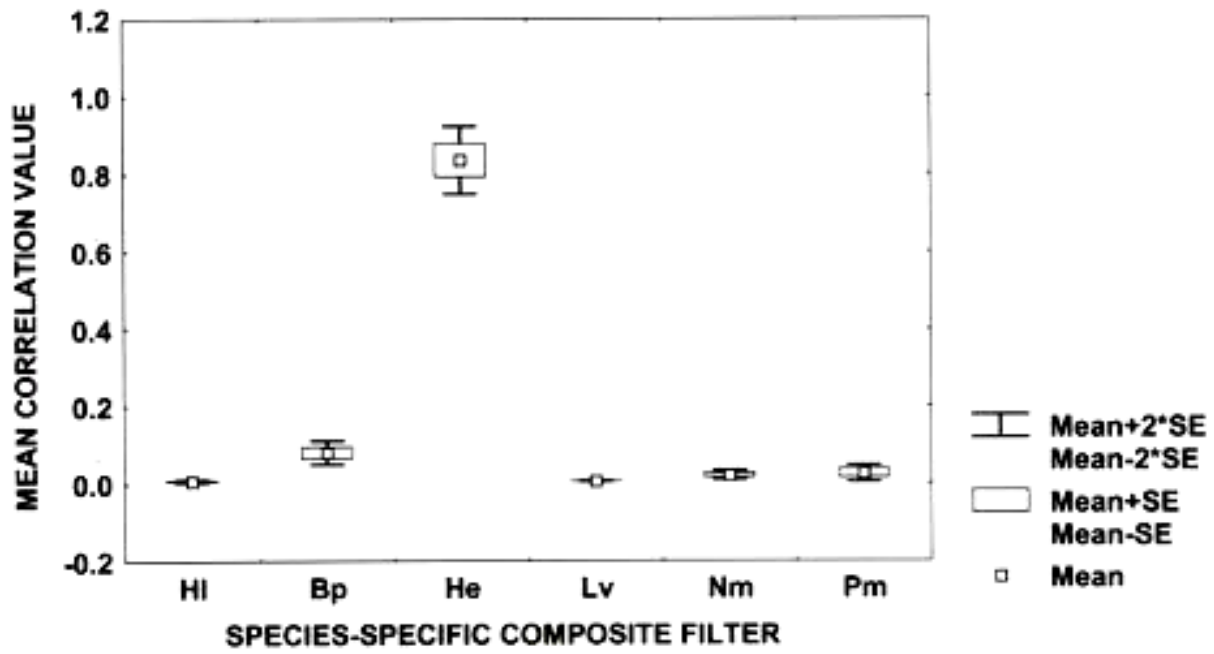

(a)
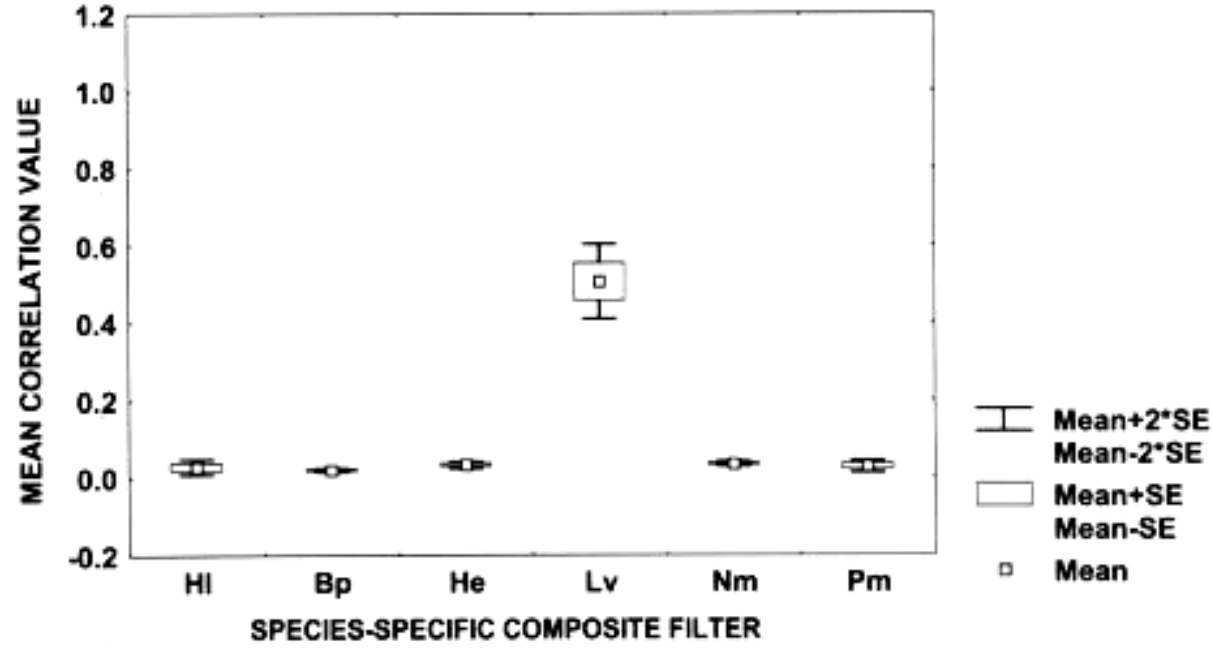

(b)

Figure 5

Correlation results for a) Heterobothrium ecuadori (He) and b) Lintonium vibex (Lv).

Boxplots show mean correlation for product of 3 color channels (RGB)

Resultados de la correlación para a) Heterobothrium ecuadori (He) y b) Lintonium vibex (Lv). Los dibujos de caja muestran la correlación promedio como producto de los 3 canales de color (RGB) 


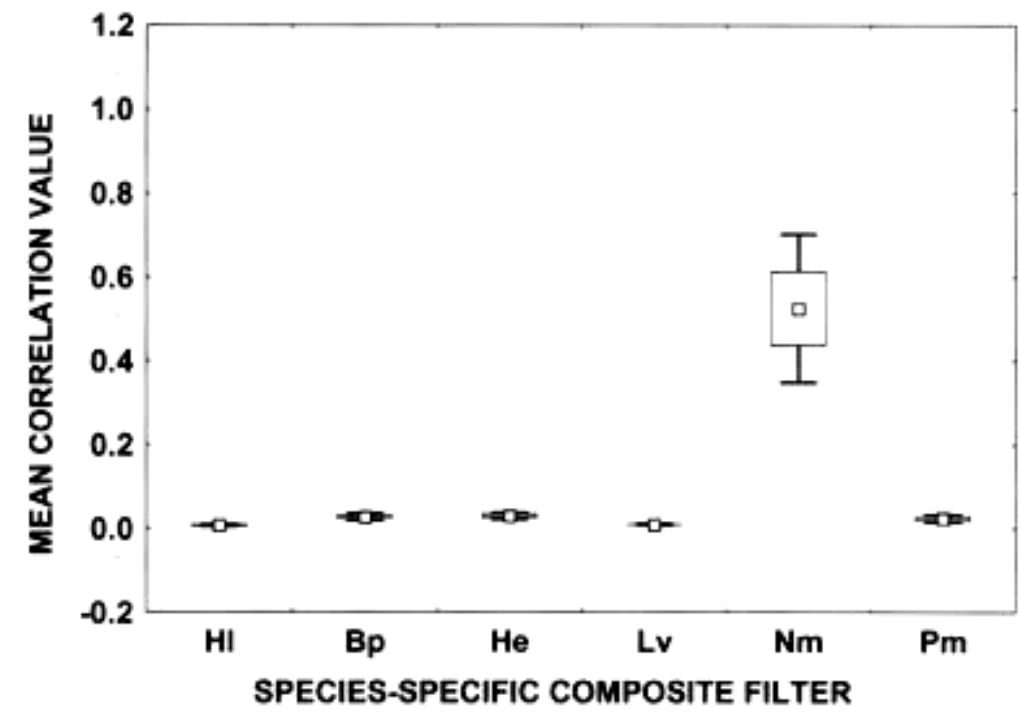

(a)
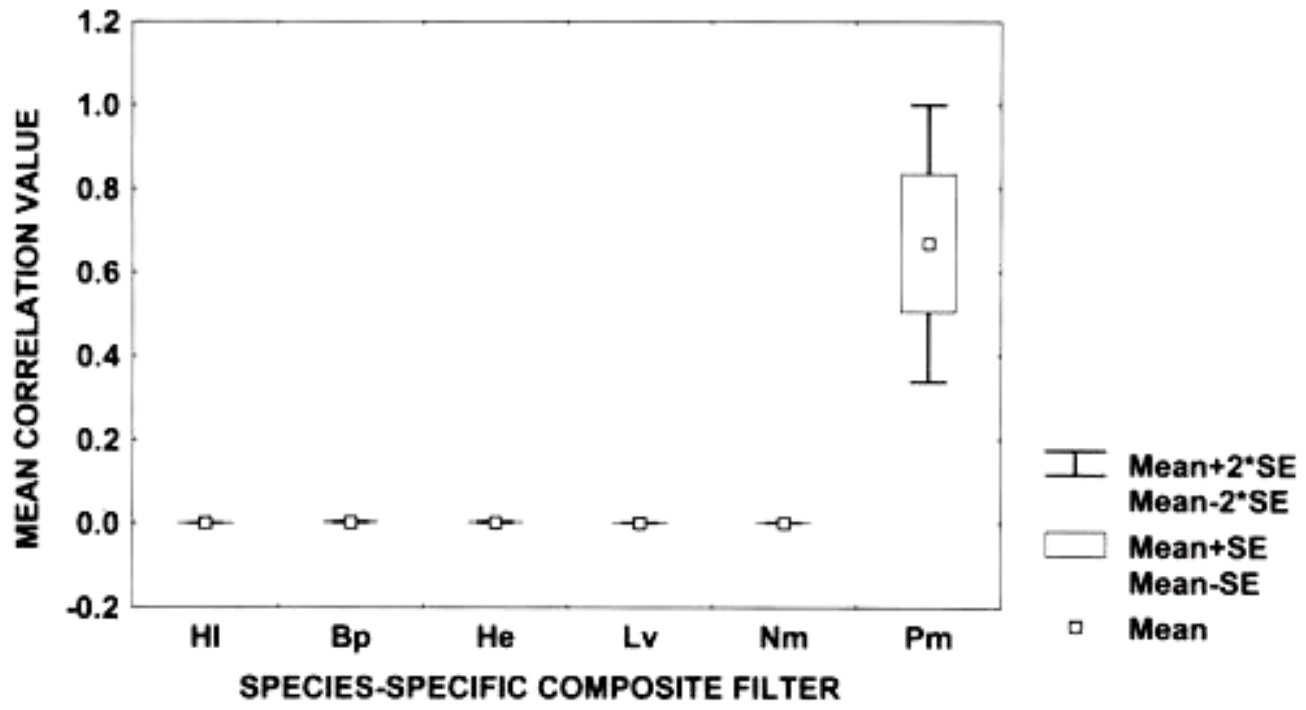

(b)

Figure 6

Correlation results for a) Neobenedenia melleni (Nm) and b) Phyllodistomum mirandai (Pm). Boxplots show mean correlation for product of 3 color channels (RGB)

Resultados de la correlación para a) Neobenedenia melleni (Nm) and b) Phyllodistomum mirandai (Pm). Los dibujos de caja muestran la correlación promedio como producto de los 3 canales de color (RGB) 
However it is necessary to consider some pitfalls involved in this mathematical technique used to discriminate platyhelminth images. One of them is the problem of imaging soft bodied organisms. Although with the fixation methods previously described, the morphology is conserved and about $90 \%$ of the internal structure can be observed, this information permits a great identification. Another problem can be the coloration in the sample, but if the sample is well sealed in balsam, the color will not change for a number of years. However, for these parasites the most important stage for identification on cover stopped slides is in the adult age only, because the sexual organs are developed. In helminths the morphology of several organs are important for their identification. The absence of sexual organisms in larvae and unripe juveniles do not permit their classification to the species level.

In summary, a successful method for the discrimination of a selected set of platyhelminth species has now been developed. However, the generation of an image library is necessary, which should include digital images of the main platyhelminth parasite species in order to apply the technique and to continue with this research.

\section{Acknowledgments}

We gratefully acknowledge Roberto Contreras Arce and María Amparo Rodríguez Santiago for their help in the collecting and staining of parasites. Part of this work was supported by a grant from the Consejo Nacional de Ciencia y Tecnología (CONACyT), México, No. 31621B and No. 36075-B. Part of this work was supported by a collaborative project between CIAD and CICESE.

\section{Literature cited}

Álvarez-Borrego J, \& MC Chávez-Sánchez. 2001. Detection of IHHN virus in shrimp tissue by digital color correlation. Aquaculture 194:1-9.

Álvarez-Borrego J, RR Mouriño-Pérez, JL Pech-Pacheco \& G Cristóbal. 2002. Invariant recognition of polychromatic images of Vibrio cholerae 01. Optical Engineering 41: 827-833.

Brooks D. 2000. Parasite systematics in the $21^{\text {st }}$ Century: Opportunities and obstacles. Memorias Institute Oswaldo Cruz, Río de Janeiro 95: 99-107.
Campos J, MS Millán, MJ Yzuel, \& C Ferreira. 1991. Colour invariant character recognition and characterbackground colour identification by multichannel matched filter. The Society of Photo-Optical Instrumentation Engineers, Inc. 1564, Optical I Information Processing Systems and Architectures III.

Cohen L. 1993. The scale representation. Institute of Electrical and Electronics Engineers, Inc. Transaction on Signal Proceedings 48(12): 3275-3292.

Cohen L. 1995. Time frequency analysis. Prentice, 299 pp. Prentice Hall Processing Series. Oppenheim AV. (series ed), Prentice Hall, New Jersey.

Duncan NJ, GA Rodríguez, D Alok \& Y Zohar. 2003. Effects of controlled delivery and acute injections of LHRHa on bullseye puffer (Sphoeroides annulatus) spawning. Aquaculture 218: 625-635.

Fajer-Ávila EJ, A Roque, G Aguilar \& N Duncan. 2004. Patterns of occurrence of the platyhelminth parasites of the wild bullseye puffer (Sphoeroides annulatus) in Sinaloa, Mexico. Journal of Parasitology 90(3): 415-418.

FAO Fisheries Department, 2000. Fishery Information, Data and Statistics Unit FISHSTAT Plus: Universal software for fishery statistical time series. Version 2.3. Dataset: Aquaculture production: quantities 1970-1999.

Gubanyi A. 1995. Morphometrics of taeniids tapeworms. I. Multivariate analysis of distance measurements of the rostellar hooks. Parasitology 28: 21-41.

Horner JL \& PD Gianino. 1984. Phase-only matched filtering. Applied Optics 23: 812-816.

Kennedy CR. 1994. Foreword. In: Pike AW and JW Lewis (eds), Parasitic Diseases of Fish 17: 623-629. Samara Publishers, Tresaith, Dyfed, UK.

Mattiucci S, G Nasutti, R Cianchi, L Mariniello, L Bullina \& L Paggi. 2000. Genetics markers (allozymes) for the identificaction of species of Hysterothylacium Ward \& Magath, 1917 (Nematoda: Anisakidae) from swordfish (Xiphias gladius) of the Mediterranean Sea. Acta Parasitologica 45:156.

Mouriño-Pérez RR. 1999. Correlación óptica a color para la identificación de diferentes estadios de Vibrio cholerae 01 Ph.D. Thesis, CICESE, Ensenada, Baja California, México. 120 pp.

Pech-Pacheco JL \& J Álvarez-Borrego. 1998. Opticaldigital system applied to the identification of five phytoplankton species. Marine Biology 132: 357-365.

Pech-Pacheco JL, J Álvarez-Borrego, G Cristóbal \& M Keil. 2003. Automatic object identification irrespective of geometric changes. Optical Engineering 42: 551-559. 
Pérez-Ponce de León G, L García-Prieto, B MendozaGarfias, V León-Regagnon \& G Pulido-Aranda. 1999. Listados faunísticos de México. Biodiversidad de helmintos parásitos de peces en la Bahía de Chamela, Jalisco. Instituto de Biología, UNAM, 51 pp.

Shinn AP, D Clers, DI Gibson \& C Sommerville. 1996. Multivariate analysis of some morphometric features of species of Gyrodactylus Nordmann, 1832 (Monogenea) parasitising British Salmonidae: light microscope based studies. Systematic Parasitology 33: 115-125.

Székely C. 1997. Possible applications of video technology and digital image processing in fish parasitology: morphological examination of the groups Apicomplexa and Myxosporea-Actinosporea by video technology. Bulletin of the European Association of Fish Pathologists 17: 81-82.
Zavala Hamz V, J Álvarez-Borrego \& A Trujillo-Ortíz. 1996. Diffraction patterns as a tool to recognize copepods. Journal of Plankton Research 18: 1471-1484.

Zavala-Hamz V \& J Álvarez-Borrego. 1997. Circular harmonic filters for the recognition of marine microorganisms. Applied Optics 36: 484-489.

Recibido el 7 de septiembre de 2005 y aceptado el 11 de mayo de 2006 